OPEN ACCESS

Edited by:

Sonja Grimm,

University of Konstanz, Germany

Reviewed by:

Bojan Vranic,

University of Belgrade, Serbia

Susann Worschech,

European University Viadrina,

Germany

*Correspondence:

Murad Nasibov

murad.nasibov@sowi.uni-

giessen.de

Specialty section:

This article was submitted to

Peace and Democracy,

a section of the journal

Frontiers in Political Science

Received: 12 May 2021

Accepted: 25 August 2021

Published: 01 October 2021

Citation:

Nasibov M (2021) Civil Society and Pro-Democracy Social Movements:

Troubled Relations Within Authoritarian

Regimes?.

Front. Polit. Sci. 3:708872.

doi: 10.3389/fpos.2021.708872

\section{Civil Society and Pro-Democracy Social Movements: Troubled Relations Within Authoritarian Regimes?}

\author{
Murad Nasibov* \\ University of Giessen, Giessen, Germany
}

This article tries to conceptually lay down the troubled relations between civil society and social movements within authoritarian regimes. This is done by, first, bringing clarity to the conceptual relationship between civil society and social movement and, then, applying it to the authoritarian context, still theoretically. Following the "hints" of the Eastern European intellectuals of the late 1970s and the 1980s and building on the appropriation of Durkheim's differentiation between mechanical solidarity and organic solidarity, the article distinguishes two types of solidarity: associative solidarity and action and collective solidarity and action. Civil society is proposed to emerge on associative solidarities (and their actions), while social movements build on collective solidarities (and their actions). Furthermore, associative and collective actions are identified to be progressive and transgressive, respectively. Consequently, the proposed theoretical account is applied theoretically to the authoritarian context and several hypotheses are proposed on the relationship between civil society and pro-democracy movement within authoritarian regimes.

Keywords: civil society, social movements, associative solidarity, collective solidarity, progressive action, transgressive action, associative action, pro-democracy movements

\section{INTRODUCTION}

The dominant narrative of civil society that emerged since the revival of the concept of the civil society reflects the particular experience of Eastern Europe in the 1980s. This particular experience, which was in the authoritarian context, has established civil society as in a constant struggle with the regime, ending with the toppling of the latter and opening the way to democratization by first installing formal democratic institutions. Such a narrative of civil society, which can be found both in liberal and republican views as discussed in the following section, leads to conceptual perplexity about the difference between civil society and pro-democracy movement. Are we referring to the same phenomena by both concepts? Or, to what extent and in what way do these two concepts overlap? How do civil society and pro-democracy movements relate to each other in the authoritarian context?

To answer these questions, the following section briefly reviews the extant literature on civil society and social movements and identifies in what core attributes they overlap. It is argued that the reason for the confusion about the relationship between these two concepts lies in their two core attributes: voluntary coming together for a common purpose and the locus of it being beyond the state, market, and family. This seemingly overlap is here referred to as the moment of confusion. It is demonstrated that scholarly efforts to bridge the gap between the two strands of literature-civil society and social movements-have been in vain. They rather only exasperated this confusion. 
Following the literature review, the author introduces a new account of his own. The proposed account follows "hints" received from the radical democratic view of Eastern European intellectuals in the late 1970s and 1980s, as discussed in the literature review section, and builds on the appropriation of Durkheim's differentiation between mechanical societies and organic societies. Additionally, it borrows some complementary insights from the organization theory.

In the proposed account, the above-discussed two attributes, core to both concepts, are differentiated without changing their overall frameworks. It is argued that the problem is not about empirical measurement and, therefore, cannot be solved by conducting more empirical studies. However, it is also not argued that a categorical error-that is, treating the same phenomena as if they are different-is the case. The problem is found to be in theoretical imprecision, and the solution offered aims to demonstrate how voluntary coming together for a common purpose-understood here as solidarity-may receive two different qualities and their locus may differ accordingly.

More specifically speaking, associative solidarity (and action), on which civil society emerges, is distinguished from collective solidarity (and action), on which social movements are built. Consequently, associative solidarity (and action) is suggested to be progressive in nature, which contrasts the transgressive nature of social movements. Finally, in this section, the conditions under which one transforms into the other are discussed.

Although the above-mentioned confusion is not exclusive to authoritarian regimes, as argued, this confusion becomes more visible in the authoritarian regime context. In other words, differentiating between civil society and pro-democracy social movement becomes more problematical in the authoritarian regime context.

After introducing a new account on solidarity and action, the fourth section first identifies several types of pro-democracy movements in general, distinguishes pro-democracy movements within authoritarian regimes from the other types, and, consequently, explores the implications of the previously proposed account of solidarity and action for civil society and pro-democracy movements within authoritarian regimes. The overall implication of the proposed account is that it allows for the conceptualization of dynamism between civil society and prodemocracy movements within authoritarian regimes. Thus, it becomes possible to look for factors that condition this dynamism. The dynamism between civil society and the prodemocracy movement is understood to be two ways: the colonization of the former by the latter and the absorption of the latter within the former. Several factors are suggested to condition this dynamism possibly in both ways. Overall, it is proposed that the absence of necessity for elaborating the details of the democratic goal may establish high transformability in either direction between civil society and pro-democracy movement within authoritarian regimes. However, some more factors need to be identified that determine the direction of influence between the two. First, the institutionalization of civil society organizations understood as a quality in a given time is supposed to be weaker under the pressure of the authoritarian regime, therefore making them vulnerable to penetration by pro-democracy movements. Secondly, the cooptation of civil society by the state is suggested to be another factor preventing associative action in civil society from transforming into collective action.

Similarly, four factors are proposed to condition the absorption or gradual establishment of the pro-democracy movement as part of civil society: the capacity of civil society to accommodate newcomers; the width of opportunities to establish new associations; the availability of alternative funding mechanisms; some freedom for meaningful associations.

Overall, the proposed account provides the necessary conceptualization for distinguishing between civil society and pro-democracy movement, which are often taken mutually exchangeable, and allows for theorizing the relationship between them. Proposals made regarding the civil society-prodemocracy movement relationship are of a measurable kind and can be tested in empirical studies.

The proposed account is based on engagement in abstract deduction and imaginative production of insights while respecting accepted relevant cautions such as those offered by List and Valentini (2016). It is ensured that the proposed theoretical arguments respect the sense of general intuition, have logical internal consistency, and are overall related well with the general framework found in the literature on the topic. When providing new concepts, efforts are put to define them as neither "too thick" nor too "thin" to be useful for abstract thinking and applicable in empirical studies.

\section{LITERATURE REVIEW}

This section briefly discusses two sources in the literature that are identified to have contributed to the current conceptual ambiguity about how civil society and pro-democracy social movements relate to each other. Although these are by no means only theoretical reasons for this ambiguity, they are the major and directly concerning ones. The first of them concerns two key qualities that were lost in the conception of civil society when it was borrowed in West in the 1980s and 1990s. The current state of grand theorising on civil society, which is broadly accepted as mission accomplie, has further cemented these losses. The second source of this ambiguity is found to be the overlap between the two core attributes of the concepts of civil society. The following paragraphs first provide a brief summary of these two sources of ambiguity and, consequently, analytically explore how they are related to each other.

Since its revival in the Polish Solidarnost movement in the late 1980 s, the concept of civil society received considerable attention in both scholarly research and practice. Although it emerged in its radical democratic interpretation (Baker, 2003), soon, interpretations emerged in both republican (e.g., Walzer, 1991; Putnam et al., 1993; Barber, 1995; Foley and Edwards, 1996; Young I. M., 2000; Putnam, 2000) and liberal (Cohen and Arato, 1992; Green, 1993; Thomas, 1997; Jensen, 2011) traditions of thought with its travel to the West. Polish intellectuals, who revived it, embedded the concept in a radical democratic view in which evolutionism was preferred over revolutionism, put the 
emphasis more on society rather than the state, and, above all, promoted self-limitation of civil society-that is, avoiding addressing regime change directly. For Polish intellectuals, changing the regime was not substantively radical enough. Instead of the political regime, they targeted the society itself. Polish evolutionism was about society's evolution rather than the evolution of the political elite. The former was thought to bring about the latter over time, and targeting the political regime was seen as disrupting this process. Societal evolutionism and selflimitation were not just a tactical choice made in front of the social regime, which was difficult to confront, as the Czechoslovakia case demonstrated. Rather, it had a normative basis (Baker, 2003, pp. 13-29). With the appropriation of the concept within the liberal and the republican views, two key characteristics of its radical democratic conception, namely, selflimitation, or self-restraint, and evolutionism, have been lost, making the authoritarian state the target of civil society and linking its function to the quality of political regime. As a result, not only have the anti-statist and society-first emphases been abandoned but also the boundary between the political sphere and the civil sphere is lost. Although it is not considered to be formally in political competition, civil society emerged as in a constant open struggle with the authoritarian regime. In this view, it, thus, becomes impossible to differentiate between civil society and a political movement that can be labeled as pro-democracy.

The abandonment of self-restraint and society-focused evolutionism in the conception of civil society develops in the following way. In the liberal view, civil society is seen as the sphere where individuals pursue their visions of the good life for which the institution of rights is the major requirement. The major task of the state is to protect the institution of rights. Thus, when the authoritarian regime curbs rights-when the liberal view of civil society is applied to the authoritarian context-civil society emerges as a sphere where citizens organize their struggle to win back their rights or respect for them. Thus, in the liberal view, the preparation of individuals for such a struggle, mobilizing citizens, and detecting, reprimanding, and rebuking the abuse of rights by the state emerge as the major task within civil society. No cooperation seems visible between civil society and the state in this view. However, civil society becomes oriented towards the state because the state, rather than society, becomes the target of civil society, and the installation of formal democratic institutions emerges as the primary goal of civil society. Although the issue of rights and democracy has equal significance in the republican view, the state-civil society relationship, in this view, is not exclusively conflictual, as some cooperation on the common societal goals other than the issues of rights, such as improving the socio-economic conditions, is permissible. To sum up, in the republican view, the state is the target of not only criticism coming from civil society but also that support for achieving what might be accepted as common goals of society. As these discussions may suggest, a pro-democracy movement within the authoritarian regime cannot be distinguished from civil society; rather, it is seen to emerge from within civil society. What distinguished the radical democratic view in this regard was that its self-restraint and society-focused evolutionism attributed to civil society create theoretical opportunity to distinguish civil society from a pro-democracy movement directly targeting the authoritarian regime and seeking to change the political regimes.

Sociological perspectives on civil society range from the third sector perspective, which focuses exclusively on an institutionally defined field (e.g., van Til (1988); Evers and Laville (2004); Brandsen et al. (2005); Valentinov (2009); van Til (2009); Vaceková and Plaček (2020); Young D. R. (2000)), to the strategic action field (e.g., Klein and Lee, 2019), which sees civil society as consisting of organizations acting with knowledge of one another under a set of common understandings about the purposes of the field, the relationships in the field, and the field's rules (Fligstein and McAdam, 2011; Fligstein and McAdam, 2015), to the arena approach, as shown in Heinrich (2005), that places it between the state, the market, and family in which citizens pursue their interests and, therefore, bears strong similarities to both Gramscian and neo-Gramscian views (e.g., Buttigieg, 1995; César Souza Ramos, 2006; Landau, 2008; Tocco, 2014; Whitehead, 2015; Fonseca, 2018), and to the sphere (Alexander, 2006; Alexander and Tognato, 2018; Alexander et al., 2019a; Alexander et al., 2019b; Alexander et al., 2020; Tognato et al., 2020) approach that includes diverse institutions outside the state apparatus and the market, norms, legal codes, and public opinion through which a civil code finds its expression, and, finally, as broad as to mean society's overall quality. There appears to be a noticeably established consensus among scholars within all these theoretical interpretations and sociological perspectives. Whether it is defined as a domain or an agent, it captures the phenomenon of people's coming together for a common purpose outside the state, the market, and the family. Two core attributes can be identified: coming together for a common purpose and the fixed locus that is outside the state, the market, and the family. The availability of this minimum specification within all its interpretations and sociological perspectives constitutes enough grounds for confusing how the concept of civil society relates to the concept of social movement. Similarly, the locus of social movement is defined outside the state, the market, and family, and as a collective action, it brings people together for a cause. The literature on social movements offers a very wide range of approaches, and their categorizations are numerous. Since it is not the purpose of this paper to provide an in-depth literature review and, consequently, a new taxonomy of social movements, which would add to many existing taxonomies, the following paragraph establishes briefly how these two core attributes are considered in the conceptualization of social movements.

People coming together for a common purpose of social movements and the locus outside the state and the market are such a common element to all the various definitions of social movement that it does not necessitate any comprehensive review of the literature to establish that. Moreover, for this reason, they do not receive any elaborate attention, as most of the emphasis is on other qualities, such as contention. For instance, it is suggested that one very common element that can be found in whatsoever definition of social movement is deployed: "promoting or resisting change to some aspect of the world" (Snow et al., 2019, p. 7). Della Porta and Diani (2006) have identified social 
movements as distinct social and political processes characterized by their conflictual relations with the power, differentiating them from other collective actions that are non-conflictual or noncontentious. McAdam et al. (2001) have focused particularly on this contentious aspect of social movements, which has two kinds: transgressive and contained depending on whether new actors are involved or not.

Although contentious or conflictual nature is the element that is emphasized, it presumes two more elements: the presence of collectivity behind and the locus of the action outside the institutional or organizational channels existing in society (Snow et al., 2019, p. 10). Collectivity is understood as two or more people coming together to pursue a common objective through joint action (Snow et al., 2019, pp. 5-6). As both the state and the market are institutional and organization domains, extra-institutionality can be understood outside the state and the market. Coming together because of common and overlapping interests and values-what defines joint action-has also been highlighted by Tarrow (2011, pp. 10-11). In his introduction to The Palgrave Handbook of Social Movements, Revolution, and Social Transformation, Berberoglu has defined social movements as collective political action, or the coming together of a large number of masses, to express outrage against dominant classes and powers, the reasons of which are exploitation or oppression (Berberoglu, 2019, p. 3). Similarly, Almeida (2019) has seen social movement as the voluntary coming of people together in joint action, rising from excluded social groups and social, economic, and environmental harms. In his 1978 book entitled From Mobilization to Revolution, Tilly (1978) has identified collective action, which constitutes one of the components of social movement, as people acting together in pursuit of common interests.

People coming together for a common purpose has been established on two grounds, opportunities and identity, which reflect two broad groups of theories. One group emphasizes resource organization-opportunities-as the major explaining factor that fits well with classic social movements of labor and national types. The other group brings in the role of identity following new social movements emerging, particularly from Europe in the 1960s and 1970s. Tilly (2004), which, through historical analysis, probes into the formation, internal structure, and claims of social movements and their relationship with the political society, has represented the former, while McGarry and Jasper (2015) have discussed how identity and identification mechanisms function between collective action and strategic choice. As a third way, Meyer et al. (2002) have attempted to bridge two different strands within the literature of social movements.

To sum up, the literature has established collective action or people voluntarily coming together for a common purpose, to it put in a more general term, which is contentious and may build on opportunities and the identity, as the basis of social movements that emerge in an extra-institutional terrain, which means outside the state and the market.

These two concepts-civil society and social movement-appear to overlap in their two core attributes.
They both are suggested to emerge outside the state and the market and build on the solidarity of people. These concepts, of course, can be differentiated based on their other characteristics. Nevertheless, differentiation of these two concepts based on further specifications would still leave this overlap confusingly unexplained, which is the major reason for their interchangeable use in both practice and scholarly literature.

Similarly, Della Porta has found empirical and theoretical overlaps between civil society and social movement "puzzling" and argued "when moving from scholarship to the 'real' world," the latter played the key role in the transition to democracy in Eastern Europe (Della Porta, 2014, pp. 137-149). Although she has emphasized the differences in the conceptualization of civil society and social movement-the former is an institutionalized field of tamed actors, while the latter is constituted of rebellious, contentious, and grassroots groups-she has avoided further explaining how these two potentially different worlds relate to each other. Returning to the question again, recently, the author has highlighted further specifications of the conceptions of civil society and social movement and attempted to link them in "the times of crisis" (Della Porta, 2020). Accordingly, the first differentiating point is their diverging emphasis on autonomy from the state and conflictual dynamism. Secondly, the author highlighted civility and contentiousness as two, respectively, distinguishing criteria. Thirdly, attention is drawn to the differences in the forms and degrees of formal institutionalization between civil society and social movement. However, having highlighted that these distinguishing qualities attributed to civil society and social movements, the author has also pointed out the limits of these criteria when empirically studied. As the author demonstrates, both "tamed" and "institutionally formalized" social movements and contentious civil society actors can be pointed out-what she captures as "hybridization." Hybridization has come, as argued, through changes on both sides-social movements moderated their repertoire of action, deepened their organizational structuration (or formal institutionalization), and depoliticized their frames, while civil society organizations turned to direct action and networked structure and started deploying more politicized discourse. Although these observations may accurately depict the developments in the past two decades or more and may be extremely helpful in bridging the gap between the two far apart strands of the literature, they still remain short of addressing the unexplained overlap in core attributes of these two concepts: locus outside the state, the market, and family and solidarity. Rather, the hybridization perspective contributes to further conceptual confusion about civil society and social movements, in which the two concepts are put at opposing ends on three linear dimensions of civility $v s$. disruptiveness, high formal institutionalization $v s$. low formal institutionalization, and contentious $v s$. conciliatory, and their approximation on the middle ground is highlighted. Indeed, in this view, civil society and social movements cease to be two qualitatively different phenomena; differences between them appear to be in the degree rather than quality. This outcome in this view reflects 
the failure to address the above-discussed theoretical overlap between the concepts at their cores.

Della Porta is not alone in these observations, as other scholars have also reported blurred boundaries between forms of popular engagement. Gready and Robins (2017) have observed that qualitatively "new" civil society deployed more of social movements' repertoire of action, which is perfectly in line with Della Porta's observation. Confirming both, Feenstra (2018) has highlighted the tendencies of blurring boundaries between voluntarism and civic action-two forms of citizen participation attributed to civil society and social movements, respectively. Daniel and Neubert (2019) have reported similar findings regarding the blurring lines between civil society and social movements in the African context. However, the reported empirical observations only attempt to bridge civil society and social movement by showing how they import from each other's repertoires of action and how, indeed, hybrid, fuzzy, or mixed forms of participation emerge from these repertoire exchanges. However, as already said above, putting them on the same dimension, even though at opposite ends, does not distinguish them qualitatively, but rather in terms of degree; second, since they are not properly distinguished, these exchanges of repertoires and emerging forms of engagement do not provide any perspective on how civil society and social movements may relate to each other.

This section explored what it identified as the sources of conceptual ambiguity about how civil society and prodemocracy movements relate to each other. The first was suggested to originate from the liberal and republican conceptions of civil society, in which the targeting of the state and the ultimate goal of installing formal democratic institutions make it impossible to differentiate civil society from the pro-democracy movement. The second, and more substantial, source of ambiguity was said to stem from the theoretical imprecision around the concepts of civil society and social movement, both of which share two overlapping attributes, namely, the voluntary coming together for a common purpose and the locus outside the state, market, and family, at the core. At the core of both sources of ambiguity lies the failure to qualitatively identify action in a way that distinguishes it from social movements. Although the same failure can be attributed to the radical democratic view, it sets an overall framework on the action within civil society by self-restraint and evolutionism. The emphasis on self-restraint, as already said above, suggested that the solidarity sought in civil society needs no masses, which is typically required when confronting the authoritarian regime as a movement, while society-focused evolutionism emphasized working with and on society, which demands mechanisms different from when the focus is on the state and the goal is changing the political regime and installing formal democratic institutions.

Partly building upon this interpretation of self-restraint and evolutionism-two core tenants of the radical democratic conception of civil society, the following section develops a new theoretical account that qualitatively distinguishes two types of solidarity and action assigned to civil society and social movement.

\section{DIFFERENTIATING BETWEEN ASSOCIATIVE SOLIDARITY AND COLLECTIVE SOLIDARITY}

As already mentioned above, the proposed account partly builds on the interpretation of the overall frame that the emphasis on self-restraint and evolutionism in Eastern European intellectual's discourse of civil society sets on the solidarity and action within civil society. On the other hand, it builds on the appropriation of the two types of solidarity identified in Emil Durkheim's sociology. Durkheim has identified two types of societies, those building on organic solidarity and those building on mechanical solidarity. Accordingly, mechanical solidarity is based on the likeness of members in society sharing the same functions, perceptions, and beliefs, while organic solidarity emerges out of complementarity between individuals with the growth in population, social differentiation, and the division of labor. In the former, the individual is a piece in the collective miniature; in the latter, the individual operates independently, but he or she is also interdependent on other independent individuals who may not resemble him or her in functions, perceptions, and beliefs. Accordingly, the move of society from the former to the latter marked the move from simplicity to relative complexity, which resulted not merely from the growth of population as such but from the increase in interaction (Durkheim, 1984). Durkheim's differentiation of solidarity types, which reflects well with Spencer's, Maine's, and Tönnies's similar classification of societies (Coser, 1984, xiv), applies to societies at large. However, its logic allows being similarly applied at the micro-level. In the mechanical solidarity, in Durkheim's account, likeness in functions, perceptions, and beliefs is not only what brings people together; however, these commonalities, which reflect the traditional experience of members, emerge as the major source of norms and rules that regulate the relationships among the people voluntarily coming together and their relations with the common goal. In this account, the mechanism between the common goal and the commonalities on which people voluntarily come together works in the direction from the latter to the former. This is, commonalities determine the common goal and, perhaps, even before that, the relationship among the members. In contrast, in organic solidarity, although there may be required to have some minimum commonalities, these commonalities are not the major source of regulation of the relationship among members. In this solidarity, members as individuals come together for a common goal and to achieve that, they develop reasonable rules of regulation among themselves-the formal institutionalization of relations on a contractual basis, which is intended to be made relatively less open to diverging interpretations. In organic solidarity, differentiation among roles and the division of jobs are the main contractualized features that require coordination and thus a hierarchy of legal authority rather than traditionally accepted power foreseen in shared beliefs. Organic solidarity may, thus, be seen as an attempt at creating patterns that are not necessarily diverging but independent from those existing in the wider environment of the initiative. In other words, the 
above-discussed qualities that organic solidarity receives are major organizational qualities (Blau and Scott, 1962). Thus, formal institutionalization, as argued, is a quality gained not only in appearance but also in substance. Although one may argue that the differentiation of roles and the division of jobs exist in mechanical solidarity, they are not pinned down in a formal regulative framework as strictly as in organic solidarity. Even when they can be at a comparative level in certain contexts, what distinguishes them is the source of this regulative framework. As already said, in mechanic solidarity, the source is the traditionally developed societal or community norms, values, beliefs, whereas in the latter, regardless of how much they are embedded in the broader normative framework of wider society, the regulative framework is the outcome of joint decisions of members. It is the source of regulation in organic solidarity that allows for the development of patterns of relationship which are distanced, although not fully, from the broader regulative norms of society. More importantly, the distance between organic solidarity and its environment also becomes formally institutionalized, shielding against, or regulating, the intrusion of the external world. Based on these assumptions, the following paragraphs provide a discussion on the emergence of solidarity and the relationship between the common ground, common goal, and institutionalization.

"Voluntary coming together for a common purpose" is the most general definition one can offer for the concept of solidarity. It requires a certain minimum common ground of values or norms to exist for individuals to be able to come together and develop joint action. However, as the number of interactions grows with the growing number of individuals, there appears a need to detail further the regulative framework among members engaging in a solidarity action and the substantiation of the common goal in reality. This need emerges from several challenges facing the survival of the solidarity established. First, even when they are informal, the regulative framework among members and the common goal is not static but subject to the continuous interpretations and re-interpretations by members, which builds, rebuilds, or collapses solidarities in society. Second, with the growing number of members, the costs of coordination increase, leading to the problem of (the lack of) cohesion and stability. Third, the boundaries of solidarity are dynamic, changing with joining or leaving new members, who may bring with themselves new interpretations or take away their stake within the solidarity, thus changing the balance of interpretations inside. Fourth, once a certain consensus is achieved among members, an inclination to extend it over new areas would naturally emerge. Failure to do so may break the already established consensuses, too. Fifth, in times of crisis in the external environment of solidarity-that is, when solidarity faces an external existential threat or becomes irrelevant to its environment, the revision of the common purpose and/or ground regarding those aspects that concern internal and/or external communication may be required. To address these challenges, there appear to be three strategic choices facing any solidarity building:

- To establish a small, intimate group of solidarity, closing it to further extension but enjoying the constructive ambiguity among themselves about the regulation and the common goal. In this case, both its action and effect can be limited.

- To grow large in size, agreeing to generalize and keep the regulative framework and the common goal loose. In this case, the solidarity continues compromising internal coherence and stability and attempts to address the problem by purchasing organization loyalty through ideological injections.

- To institutionalize the initially setup solidarity and, thus, be able to grow gradually and procedurally. In this case, the initially agreed regulative framework and the common goal can be subject to changes only through agreed procedures and members' behaviors are controlled accordingly.

The first strategic choice is made when the solidarity agrees to have a very limited effect on the outside world or is not interested in it at all. Clubs, societies, or fraternities are an example of the first type. The second type, if successfully realized, develops into a social movement, while the third type is what makes associations. Motivated to connect with others closely, people prefer the second type only when the third type-the optimal option in terms of the trade-off between the effect, risks, and detailedness of the solidarity among the three strategic choices-seems infeasible or impossible to realize meaningfully and to achieve the common goal.

The strategic choice is made not only once but continuously in the action of the solidarity group throughout its existence. Action is understood as the solidarity group's working itself out towards a common purpose. Institutionalizing the common purpose and the common ground, their elaboration through internal rules and structures, which leads to the professionalization and even bureaucratization of members, enables and requires small groups to carry out specific programs on a routine basis, avoiding those actions that would create any of the challenges described above. Such solidarity is referred to as associative solidarity, and its action is accordingly defined as associative action. The type of solidarity making civil society is, thus, of the associative type.

Associative solidarity is distinguished from collective solidarity, which characterizes social movements. Collective solidarity may emerge from both within civil society and outside it, for instance, in political society (political parties and their affiliate organizations). It emerges from within civil society with the transformation of associative solidarity. When faced with an external existential threat or risk of becoming irrelevant to their environment, as an alternative to declining and disappearing, civil society organizations may choose to enlarge their solidarity with other groups or individuals to sustain their existence against the inhibiting environment. In this transformation, a civil society organization opens its doors to other similar organizations and individuals from wider society, aims to reach beyond the boundaries of civil society, and makes its discourse more abstract and action more relevant-less institutionalized and structured-for the engagement of masses. Making its discourse abstract is a process through which the civil society organization withdraws from its previous commitment to the detailed elaboration of its goals 
and restrains itself with its general account, usually found in its mission, or commits itself to create a conducive environment for the achievement of that mission. Subsequently, its actions are accordingly revised, becoming less routine, less structured, and less professional and bureaucratic. In doing so, it frees itself from concerns about cohesion and stability, which are, as discussed above. However, above these, it largely frees itself from the concern of being contentious. This is because once the actions of civil society organizations change from routine, professional, and bureaucratic work, requiring it to play by the rules, to less so, it is left with no concern of disrupting its working process by becoming contentious or risking it. In other words, it agrees to the fact that the types of activities in which masses can engage run the risk of turning violent and radical, even if it is not what is originally intended.

As already said, the transformation of associative solidarity into collective solidarity is only one of the outcomes that civil society organizations that face existential threats or risks becoming irrelevant to their environment may end up with. Alternatively, they may decline and disappear either by themselves or by joining another organization. Several factors can be crucial for these organizations' strategic choices at times of crisis. In short, the organization members should be convinced that the current way of action is not effective anymore, even if feasible, and that the imagined new ways of action would be less costly than the current ones. In other words, they need to see opportunity in the transformation to collective solidarity. However, the institutional form and the depth of organizational structuration should allow such transformation and not make it costly. Moreover, the extent of the cooptation of the organization by the state through regulation, funding, and institutional membership would be a factor preventing the organization from such transformation.

Civil society organizations' transformation from associative solidarity to collective solidarity, and the respective transformation in action, can be defined as their colonization by social movement(s) emerging from either inside the civil society or outside it. However, colonization of civil society is only one side of the relationship between civil society and social movement(s). Contrary to colonization, social movement(s) can be dragged into civil society and dissolved in it. That means social movement(s) may become established within or absorbed by civil society. This would happen when collective solidarity faces severe obstacles and bears no results, while opportunities emerge within civil society to come together for similar purposes and progress towards them. The larger the opportunities for organizing and action within civil society, the more associative the solidarity, which is preferred over collective solidarity. Therefore, social movements can hardly emerge from within such a civil society. However, social movements emerging from outside civil society can be expected to be absorbed by or dissolved within civil society when opportunities for associative solidarity within civil society are large.

The following few examples can further illuminate the absorption of social movement(s) by civil society. For instance, social movement organizations that emerged in Eastern Europe in the 1970s and 1980s were absorbed within civil society in the 1990s with the opening of space for civil society following the regime change and particularly with the facilitation of Western funding that flew following the collapse of socialist regimes (Celichowski, 2004).

An alternative example would be the loosely organized democracy movement of the 1980s in China that came to an end not in Tiananmen square but with the emerging Chinese civil society in the 1990s. If the Chinese democracy movement of the 1980s emerged when there was a severely restrictive environment for civil society, it was dissolved within civil society opened by the new political opportunities. The new political opportunities for Chinese civil society emerged with the government's strategy of relieving its continuously increasing social burden on nongovernmental organizations and local community groups ( $\mathrm{Ma}$, 2006; Ma, 2002). The Chinese state continues similar policy towards civil society today and even seems to have well understood its absorption capacity for social movements (Huang, 2015; Tai, 2015; Teets, 2015; Yuanfeng, 2015; Zhao et al., 2016). Although civil society in China is under heavy control and closely coopted by the government, certain autonomy is recognized that does not threaten the regime's interests (Whitehead, 2015; Kang, 2018; Spires, 2019). However, the limits of autonomy are not static, rather dynamically changing forward and backward-a purposeful strategy chosen by the government that aims at more than relieving the socioeconomic burden on its shoulders (Huang, 2018). The Chinese case suggests that although coopted and under tight control, burgeoning civil society organizations may have the capacity to absorb social movement potential.

The case of the Green movement in Germany aligns well with the argument proposed here that social movements become absorbed within civil society when opportunities for organizing and meaningful associative action exist. The Green movement growing from the late 1960s and throughout the 1970s at the grassroots level became established within both civil society and political society starting from the 1980s, consequently experiencing incompatibility between its grassroots democracy and new forms of actions (Bomberg, 1992; Poguntke, 1993).

The decade of the 1990s without social movements all over the globe can be accounted to burgeoning civil society organizations, while the globally emerging new generation of movements from the beginning of the 2000s to the failure of civil society addressed deep structural injustices caused by global neoliberalism (Tarrow, 2011, xv). The observations made by Della Porta (2020) and others (Daniel and Neubert, 2019; Feenstra, 2018; Gready and Robins, 2017) have confirmed the transformation of associative action into collective action with a new crisis in the past two decades. Failing to capture it as a qualitative change, they depict it as exchanges of repertoire between civil society organizations and social movements or hybridization.

The third alternative is the parallel existence of social movements and civil society when the former fails to colonize the latter. Moreover, the opportunities for organizing and meaningful associative action possessed by the latter are not enough to absorb the former in itself and dissolve it. The parallel existence, however, does not mean that they are unaffected by each other. Both exchanges are at the resource 
and discourse levels while experiencing tensions from time to time. This view proposes a more complex picture than the rejecting or sympathizing dichotomy offered by Alexander (2006). He has suggested that the establishment within civil society mostly rejects social movement(s) and only rarely sympathizes with them because of the latter's disruptive actions that breach the civil code and come close to it and its challenges to the civil establishment.

These discussions on associative solidarity (action) and collective solidarity (action) have already provided clues to the arguments on the locus of civil society and social movements. One key difference between associative solidarity and collective solidarity is proposed to determine how civil society and social movements differ in their locus within society. Associative action-which builds on more intimate solidarity of small group but aims to grow, and therefore whose organization and actions become routinized, formally institutionalized, professionalized, and bureaucratic over time-is progressoriented in that it consists of activities that target gradually improving certain conditions concerning inclusion or exclusion of parts of society or the benefits of the whole. The achievement of the goal is not necessarily conditional upon the size the solidarity retains, and therefore, extending its organization beyond the civil sphere is not in the ultimate interest. Thus, progressiveness-being progress-oriented-is a key characteristic of associative action.

In contrast, collective action is transgressive in two interdependent senses. First, it pushes beyond boundaries within society. If it originates from within civil society, it aims to extend its action beyond the boundaries of civil society. If it emerges outside civil society, it pushes through the boundaries of civil society. Social movements' inclination to totalizing efforts in society does not allow them to remain within the limits of any sphere within society.

Second and related to the first, social movements push the boundaries of the accepted civil code. They do so in two ways: first, by aiming at totally or substantially altering its content; second, when they cross over boundaries within society, they also breach the accepted civil code. A hypothetical example for the latter can better explain it. When a social movement attempts to reach, for instance, potential supporters within the state apparatus and achieves that, this results unavoidably in the breaching of legal codes. The breaching of legal codes results in the breaching of the civil code as the former is the manifestation of the latter at the respective institutional level. This happens in two ways: first, in the recruitment process of supporters from inside the state bureaucracy; second, in the acts of those supporters who are already recruited by the movement and aim to support the movement.

To sum up, this section distinguished two different types of solidarity: associative and collective and their actions, respectively. Action is understood as solidarity working itself out towards a common purpose. Consequently, progressive and transgressive qualities attributed, respectively, to associative and collective actions were identified. Subsequently, this section addressed what was identified at the beginning as the moment of confusion-the overlap between the two core attributes of civil society and social movement, namely, "voluntary coming together for a common purpose" and their locus. It was suggested that civil society resides on associative solidarities expressed in action, while social movements are built on collective solidarity expressed in collective action.

Secondly, to address the problem of overlap in locus, this section suggested that associative action on which civil society emerges is progressive-that is, progress-oriented-and therefore, it does not aim to reach beyond boundaries and totalize efforts across spheres within society in a manner sought by collective solidarity (and action). Therefore, it can be pinned down to a certain sphere.

In contrast, collective action on which social movements emerge can originate both within and outside civil society. Regardless of where it originates, social movements aim to transgress boundaries-reaching across boundaries within society and totalizing efforts, resulting in the breaching of the civil code. Given these qualities, it is not possible to pin down social movement in a certain sphere.

Finally, the relationship between civil society and social movement is suggested to be of three types: i) colonization of civil society by the social movement, ii) absorption of the social movement by civil society, and iii) the parallel existence of two. The following section applies these conclusions to the authoritarian context.

The following section applies the above proposed theoretical account to understand pro-democracy movements and their relation to civil society. The problem of overlap appears particularly important in the case of pro-democracy movements, which can be detected in the interchangeable use of the concepts not only in public discourse but also in scholarly works.

\section{TROUBLED RELATIONS BETWEEN CIVIL SOCIETY AND SOCIAL MOVEMENTS WITHIN AUTHORITARIAN REGIMES}

Before elaborating on the relationship between the prodemocracy movement and civil society, one needs to identify how the pro-democracy adjective specifies the movements At least four ways of this can be distinguished:

- Aiming to bring the establishment and/or ensure the proper functioning of democratic government institutions in a society where they do not exist at all or have a just façade value.

- Aiming to eliminate structural injustices in a society where formal democratic institutions and at least a certain significant level of democracy exist, by bringing more democratic participation, accountability, and control.

- Aiming to prevent declining the status of democracy in a society where the democratic quality of institutions is gradually eroding while in parallel power is being consolidated in a few hands.

- Aiming to protect democratic institutions against a sudden breakdown threatened by military or any other type of coup d'etat. 
These can serve at best as the ideal-typical types of prodemocracy movements, while on the ground, the line between these categories can be very blurred. As it might have already been obvious, they are identified according to political regime qualities. The first type concerns authoritarian regimes, while the second type is typical of established or so-called new democracies. The third relates to the regime that is in the gradual process of losing its democratic quality, while the last type emerges in a society where democratic quality has already been significantly lost so that it allows the illegitimate capture of power and forceful regime change by a group of people.

In addition to these types, a popular pro-democracy movement can be identified: the type of movement that deploys the pro-democracy slogan in a populist way to cloak its essentially totalitarian or anti-democratic nature. However, distinguishing between the second type above and this populist type can be challenging, as it requires exposing the understanding of democracy in their discourses. They are both seen as antiestablishment as both claim the existing elite to sustain deep structural injustices to exist in society.

Having very generally identified what can stand as a prodemocracy movement, the rest of the discussion turns to propose theoretically the ways civil society and the first type of prodemocracy movements identified above relate to each other. This type of pro-democracy movement is the one, as already noted, which emerges in an authoritarian context where formal democratic institutions do not exist at all or have merely a façade value. In these societies, the purpose of the pro-democracy movement is to either establish formal democratic institutions in the first place or, if they do exist, to ensure their proper functioning. Although the proposed theoretical account can be applied to all the types of pro-democracy movements, the purpose of picking up only the pro-democracy movement within an authoritarian regime for further discussion is that, in the authoritarian context, it becomes particularly difficult to distinguish between pro-democracy movements and civil society.

Several general hypotheses are put forward regarding the relationship between civil society and a pro-democracy movement in the authoritarian context. The first hypothesis concerns the overall dynamism between civil society a prodemocracy movement in general, while the remaining hypotheses concern the factors conditioning the transformation from associative action into collective action and vice versa.

The first hypothesis is that the lack of necessity to elaborate the details of the aimed democratic goal in the authoritarian context increases transformativity between civil society and a prodemocracy movement. The lack of necessity is assumed to stem from the large distance or difference between the existing authoritarian and the democratic regime, which both civil society and a pro-democracy movement aim at. Since the context is too far away from the aimed goal, its elaborateness is not required. Only when society progresses towards a democratic regime, questions about its elaborateness can be expected to be raised. When such questions are raised in the authoritarian context, they may simply be irrelevant as society may seem too far away from that elaborateness. In such contexts, the discourses in civil society and a pro-democracy movement may largely overlap, which would facilitate the transformation of associative action into collective action or vice versa, and, subsequently, blur the borderlines between pro-democracy social movements and civil society.

The cooptation of civil society organizations by the state within authoritarian regimes is well depicted in numerous empirical studies (e.g., Reuter and Robertson, 2015; Holdo, 2019; Alqatabry and Butcher, 2020). The state of cooptation by the state, thus, can be one of the factors negatively conditioning civil society organizations' transformation from associative action to collective action. The state of cooptation can be determined by the overall regulative framework, the provision of funding by the government, and institutional linkages created through government-controlled platforms. Thus, one may reasonably argue that the stricter the civil society organizations are coopted by the state, the less the probability is for civil society organizations to transform from associative action into collective action.

As already discussed in the previous section, the state of formal institutionalization can be the second factor conditioning civil society organizations' transformation from associative action to collective action. This argument can be embedded in the organization theory literature, particularly the neoclassic organization theory, which explores the relationship between the formal and informal organization and emphasizes the importance of formal regulation within the organization as a shield against the influences of the external environment and the internal deviations resulting from that (e.g., Selznick, 1957; Blau and Scott, 1962; Litterer, 1963; Barnard, 1969; Litterer, 1969; Stinchcombe, 1970). Given the pressure of the authoritarian regime on civil society organizations, one may expect to find civil society organizations to suffer from poor institutionalization and, thus, the lack of institutional resistance to transforming from associative action into collective action. Thus, one may hypothesize that the lack of formal institutionalization in civil society organizations within authoritarian regimes positively relates to their transformation from associative action into collective action.

In contrast, one would expect that the absorption of the prodemocracy movement within civil society depends on the overall capacity of civil society to drive many within the pro-democracy movement to shift away from collective action and turn to associative action. The capacity required for the gradual establishment of the movement as part of civil society-that is, its absorption by civil society-can be logically thought to include the following:

- The overall size of civil society to accommodate a large number of newcomers

- Opportunities to establish new associative solidarities

- The extent of available alternative funding mechanisms

- At least some minimum freedom to pursue meaningful associative action

Finally, both the absence of the required capacity of civil society to absorb the pro-democracy movement and the 
incapability of the movement to colonize civil society would consequently result in what have already been previously identified as their parallel existence. Although such a parallel existence may feature both exchanges in discourse and practice in other contexts, in the authoritarian context, this relationship can be expected to have the tension more institutionalized, as the cooperation of civil society organizations with the government may seem as counter-productive towards the democratic goal by the pro-democracy movement, while the actions of the prodemocracy movement can be considered to be too radical and less sensitive to the overall country context.

\section{CONCLUDING REMARKS}

This paper attempted first to differentiate civil society and social movements based on the sociology of solidarity and action and, then, demonstrated how troubled relations can there exist between civil society and pro-democracy movement within the authoritarian context. Although both concepts received very diverse scholarly treatments, there still lacks a close-up approach on the sociology of solidarity and action in the studies on civil society and social movements, which particularly, but not exclusively, causes a problem in addressing civil society and pro-democracy movements within authoritarian regimes, reflected in the mutually exchangeable use of the concepts both in the academic literature and public discourse. Establishing associative solidarity and action as different from collective solidarity and action enabled not only to differentiate civil society and pro-democracy movement within the authoritarian context and social movement in general but also, more importantly, to hypothesize about the dynamic relationship between them. The way the proposed account hypothesizes the relationship between civil society and social movement renders potential for theorizing that reaches far beyond what the extant literature, which focuses on the mutual exchange of repertoire, offers. It enables us to better understand, for instance, civil society organizations abstaining from pro-democracy movements, particularly within authoritarian regimes and in general.

By engaging purely in theoretical discussions, the purpose of this article was to provide a new theoretical account that would

\section{REFERENCES}

Alexander, J. C., Lund, A., and Voyer, A. M. (2019a). The Nordic Civil Sphere. Polity Press.

Alexander, J. C., Palmer, D. A., Park, S., and Shuk-Mei Ku, A. (2019b). The Civil Sphere in East Asia. Cambridge University Press.

Alexander, J. C., Stack, T., and Khosrokhavar, F. (2020). Breaching the Civil Order: Radicalism and the Civil Sphere. Cambridge University Press.

Alexander, J. C. (2006). The Civil Sphere. Oxford University Press. Available at: https://ebookcentral.proquest.com/lib/gla/detail.action?docID=281262.

Alexander, J. C., and Tognato, C. (2018). The Civil Sphere in Latin America. Cambridge University Press.

Almeida, P. (2019). Social Movements: The Structure of Collective Mobilization / Paul Almeida. University of California Press. feed into the theoretical discussions on civil society and social movements, on the one hand, trigger new empirical studies, on the other hand, and thus, hopefully, contribute to the construction of better linkage between the strands of literature on civil society and social movements. Although the hypotheses offered in the last section are well applicable, subjecting them to test requires series of studies, which is out of the scope of a single paper. However, they require to be tested through many studies in order to gain empirical support. For this, they provide plenty of opportunities that can be picked up in future research.

\section{DATA AVAILABILITY STATEMENT}

The original contributions presented in the study are included in the article/supplementary material; further inquiries can be directed to the corresponding author.

\section{AUTHOR CONTRIBUTIONS}

The author confirms being the sole contributor to this work and has approved it for publication.

\section{FUNDING}

Justus-Liebig University generously pays for half of the publication fee from its open access publication fund, while the other half is paid by the author, thanks to the additional annual support made available by DAAD. The author is a DAAD's doctoral research scholarship holder.

\section{ACKNOWLEDGMENTS}

I would like to thank Shabnam Karimova - a BWL master student at the Justus-Liebig University of Giessen at the time of submitting this paper - for all the discussions we had together on the initial idea of this paper and all criticisms she passionately made in defense of the radical democratic spirit.

Alqatabry, H., and Butcher, C. (2020). Humanitarian Aid in yemen: Collaboration or Co-optation? J. Peacebuilding Develop. 15 (2), 250-255. doi:10.1177/ 1542316620907573

A. McGarry and J. M. Jasper (Editors) (2015). Politics, History and Social Change. The Identity Dilemma: Social Movements and Collective Identity (Temple University Press).

Baker, G. (2003). Civil Society and Democratic Theory: Alternative Voices. 1st ed. Taylor \& Francis.

Barber, B. R. (1995). Searching for Civil Society. Nat. Civic Rev. 84 (2), 114-118. doi:10.1002/ncr.4100840205

Barnard, C. I. (1969). "Formal Organization," in Wiley Series in Management and Administration. Organizations: Structure and Behavior. Editor J. A. Litterer. 2nd ed. (John Wiley), Vol. 1, 40-50.

B. Berberoglu (Editors) (2019). The Palgrave Handbook of Social Movements, Revolution, and Social Transformation (Springer International Publishing). doi:10.1007/978-3-319-92354-3 
Blau, P. M., and Scott, W. R. (1962). Formal Organizations: A Comparative Approach / by Peter M. Blau and W. Richard Scott. Chandler publications in anthropology. San Francisco: Chandler Pub. Co.

Bomberg, E. (1992). The German Greens and the European Community: Dilemmas of a Movement-party. Environ. Polit. 1 (4), 160-185. doi:10.1080/ 09644019208414050

Brandsen, T., van de Donk, W., and Putters, K. (2005). Griffins or Chameleons? Hybridity as a Permanent and Inevitable Characteristic of the Third Sector. Int. J. Public Adm. 28 (9-10), 749-765. doi:10.1081/PAD-200067320

Buttigieg, J. A. (1995). Gramsci on Civil Society. boundary 222 (3), 1-32. doi:10.2307/303721

Celichowski, J. (2004). "Civil Society in Eastern Europe: Growth without Engagement," in Exploring Civil Society: Political and Cultural Contexts. Editors M. Glasius, D. Lewis, and H. Seckinelgin (Routledge), 62-69. doi:10.4324/9780203358290-16

César Souza Ramos, L. (2006). Civil Society in an Age of Globalization: A NeoGramscian Perspective. J. Civil Soc. 2 (2), 143-163. doi:10.1080/ 17448680600905940

Cohen, J. L., and Arato, A. (1992). Civil Society and Political theoryStudies in Contemporary German Social Thought. MIT Press.

Coser, L. (1984). "Introduction," in Contemporary Social Theory. The Division of Labour in Society. Editor É. Durkheim (Macmillan), ix-xxxi.

Daniel, A., and Neubert, D. (2019). Civil Society and Social Movements: Conceptual Insights and Challenges in African Contexts. Crit. Afr. Stud. 11 (2), 176-192. doi:10.1080/21681392.2019.1613902

Della Porta, D. (2020). Building Bridges: Social Movements and Civil Society in Times of Crisis. VOLUNTAS 31 (5), 938-948. doi:10.1007/s11266-020-00199-5

Della Porta, D. (2014). "Democratization from below: Civil Society versus Social Movements?" in Civil Society and Democracy Promotion. Editors T. Beichelt, I. Hahn-Fuhr, F. Schimmelfennig, and S. Worschech (Palgrave Macmillan UK), 137-149. doi:10.1057/9781137291097_7

Della Porta, D., and Diani, M. (2006). Social Movements: An Introduction / Donatella Della Porta and Mario Diani. 2nd ed. Blackwell.

E. Durkheim (Editors) (1984). Contemporary Social Theory. The Division of Labour in Society (Macmillan).

Evers, A., and Laville, J.-L. (2004). The Third Sector in Europe. Globalization and Welfare. Edward Elgar. Available at: http://site.ebrary.com/lib/alltitles/ docDetail.action?docID $=10471502$.

Feenstra, R. A. (2018). Blurring the Lines between Civil Society, Volunteering and Social Movements. A Reflection on Redrawing Boundaries Inspired by the Spanish Case. Voluntas 29 (6), 1202-1215. doi:10.1007/s11266-018-00056-6

Fligstein, N., and McAdam, D. (2015). A Theory of fields. Oxford Univ. Press.

Fligstein, N., and McAdam, D. (2011). Toward a General Theory of Strategic Action fields. Sociological Theor. 29 (1), 1-26. doi:10.1111/j.14679558.2010.01385.x

Foley, M. W., and Edwards, B. (1996). The Paradox of Civil Society. J. Democracy 7 (3), 38-52. doi:10.1353/jod.1996.0048

Fonseca, M. (2018). Gramsci's Critique of Civil Society: Towards a New Concept of Hegemony. Routledge.

Gready, P., and Robins, S. (2017). Rethinking Civil Society and Transitional justice: Lessons from Social Movements and 'new' Civil Society. Int. J. Hum. Rights 21 (7), 956-975. doi:10.1080/13642987.2017.1313237

Green, D. G. (1993). Reinventing Civil Society: The Rediscovery of Welfare without Politics / David G. Green. IEA Health and Welfare Unit. Choice in welfare series: no.17.

Heinrich, V. F. (2005). Studying Civil Society Across the World: Exploring the Thorny Issues of Conceptualization and Measurement. J. Civil Soc. 1 (3), 211-228. doi:10.1080/17448680500484749

Holdo, M. (2019). Cooptation and Non-Cooptation: Elite Strategies in Response to Social Protest. Soc. Move. Stud. 18 (4), 444-462. doi:10.1080/ 14742837.2019.1577133

Huang, M. (2015). The "Institutional Space" of Civil Society in China: The Legal Framework of Civil Society Organizations. J. Contemp. East Asia Stud. 4 (1), 55-73. doi:10.1080/24761028.2015.11869081

Huang, V. G. (2018). Floating Control: Examining Factors Affecting the Management of the Civil Society Sector in Authoritarian china. Soc. Move. Stud. 17 (4), 378-392. doi:10.1080/14742837.2018.1460264
J. A. Litterer (Editors) (1963). Organizations: Systems, Control and Adaption (John Wiley \& Sons), Vol. 2.

J. A. Litterer (Editors) (1969). Wiley Series in Management and Administration. Organizations: Structure and Behavior. 2nd ed. (John Wiley), Vol. 1.

Jensen, M. (2011). "Civil Society in liberal Democracy," in Routledge Studies in Contemporary Philosophy (Routledge), 26.

Kang, X. (2018). Moving toward Neo-Totalitarianism: A Political-Sociological Analysis of the Evolution of Administrative Absorption of Society in china. Nonprofit Policy Forum 9 (1). doi:10.1515/npf-2017-0026

Klein, S., and Lee, C.-S. (2019). Towards a Dynamic Theory of Civil Society: The Politics of Forward and Backward Infiltration. Sociological Theor. 37 (1), 62-88. doi:10.1177/0735275119830451

Landau, I. (2008). Law and Civil Society in cambodia and Vietnam: A Gramscian Perspective. J. Contemp. Asia 38 (2), 244-258. doi:10.1080/00472330701822322

List, C., and Valentini, L. (2016). "The Methodology of Political Theory," in The Oxford Handbook of Philosophical Methodology. Editors H. Cappelen, T. Gendler, and J. Hawthorne. Oxford Handbooks in Philosophy. (Oxford University Press), 668-704. doi:10.1093/oxfordhb/9780199668779.013.10

Ma, Q. (2006). "Non-governmental Organizations in Contemporary China: Paving the Way to Civil Society? / Qiusha Ma," in Routledge Contemporary China Series 6 (Routledge).

Ma, Q. (2002). The Governance of Ngos in china since 1978: How Much Autonomy? Nonprofit Voluntary Sector Q. 31 (3), 305-328. doi:10.1177/ 0899764002313001

McAdam, D., Tarrow, S. G., and Tilly, C. (2001). Dynamics of Contention. Cambridge studies in contentious politics. New York and London: Cambridge University Press.

Meyer, D. S., Whittier, N., and Robnett, B. (2002). Social Movements: Identity, Culture and the State. Oxford University Press.

Poguntke, T. (1993). Goodbye to Movement Politics? Organisational Adaptation of the German green Party. Environ. Polit. 2 (3), 379-404. doi:10.1080/ 09644019308414086

Putnam, R. D. (2000). Bowling Alone: The Collapse and Revival of American Community / Robert D. Putnam. Simon \& Schuster.

Putnam, R. D., Leonardi, R., and Nanetti, R. Y. (1993). Making Democracy Work: Civic Traditions in Modern Italy. Princeton University Press.

Reuter, O. J., and Robertson, G. B. (2015). Legislatures, Cooptation, and Social Protest in Contemporary Authoritarian Regimes. J. Polit. 77 (1), 235-248. doi:10.1086/678390

Selznick, P. (1957). Leadership in Administration: A Sociological Interpretation. Harper \& Row.

Snow, D. A., Soule, S. A., Kriesi, H., and McCammon, H. J. (2019). "The Wiley Blackwell Companion to Social Movements (Second Edition)," in Wiley Blackwell Companions to Sociology (John Wiley \& Sons).

Spires, A. J. (2019). Regulation as Political Control: China's First Charity Law and its Implications for Civil Society. Nonprofit Voluntary Sector Q. 49 (3), 571-588. doi:10.1177/0899764019883939

Stinchcombe, A. L. (1970). Social Structure and Organizations. Handbook of Organizations, 142-193.

Tai, J. W. (2015). Building Civil Society in Authoritarian China, 20. Springer International Publishing. doi:10.1007/978-3-319-03665-6

Tarrow, S. G. (2011). Power in Movement: Social Movements and Contentious Politics / Sidney G. Tarrow (Rev. \& Updated 3rd ed.). Cambridge studies in comparative politics. Cambridge University Press.

Teets, J. C. (2015). The Evolution of Civil Society in Yunnan Province: Contending Models of Civil Society Management in china. J. Contemp. China 24 (91), 158-175. doi:10.1080/10670564.2014.918417

Thomas, A. (1997). Liberal Republicanism and the Role of Civil Society. Democratization 4 (3), 26-44. doi:10.1080/13510349708403524

Tilly, C. (1978). From Mobilization to Revolution. 1st ed. Random House.

Tilly, C. (2004). Social Movements, 1768 - 2004. Paradigm Publ.

Tocco, L. (2014). "Civil Society in Turkey: A reading of Kadin Gazetesi through a Gramscian Lens," in Contemporary Turkey at a Glance: Interdisciplinary Perspectives on Local and Translocal Dynamics. Editors K. Kamp, A. Kaya, E. F. Keyman, and O. Onursal Besgul (Springer Fachmedien Wiesbaden), 57-73. doi:10.1007/978-3-658-04916-4_6

Tognato, C., Jaworsky, B. N., and Alexander, J. C. (2020). The Courage for Civil Repair: Narrating the Righteous in International Migration / Carlo Tognato, 
Bernadette Nadya Jaworsky, Jeffrey C. Alexander. Cultural Sociology. Palgrave Macmillan.

Vaceková, G., and Plaček, M. (2020). "Historical Analysis of Third Sector," in Global Encyclopedia of Public Administration, Public Policy, and Governance. Editor A. Farazmand (Springer International Publishing), 1-6. doi:10.1007/ 978-3-319-31816-5_3907-1

Valentinov, V. (2009). Mapping the Third Sector in John R. Commons' Typology of Transactions. J. Econ. Issues 43 (4), 917-930. doi:10.2753/JEI00213624430405

van Til, J. (2009). A Paradigm Shift in Third Sector Theory and Practice. Am. Behav. Scientist 52 (7), 1069-1081. doi:10.1177/0002764208327675

van Til, J. (1988). Mapping the Third Sector: Voluntarism in a Changing Social Economy / Jon Van Til. Foundation Center.

Walzer, M. (1991). The Idea of Civil Society: a Path to Social Reconstruction. Dissent 39, 293-304.

Whitehead, J. (2015). Au Retour aGramsci: Reflections on Civil Society, Political Society and the State in South Asia. J. Contemp. Asia 45 (4), 660-676. doi:10.1080/00472336.2015.1045725

Young, D. R. (2000a). Alternative Models of Government-Nonprofit Sector Relations: Theoretical and International Perspectives. Nonprofit Voluntary Sector Q. 29, 149-172. (Print). doi:10.1177/0899764000291009

Young, I. M. (2000b). Inclusion and Democracy. Oxford political theory. Oxford University Press.
Yuanfeng, Z. (2015). Dependent Interdependence: The Complicated Dance of Government-Nonprofit Relations in China. Voluntas 26 (6), 2395-2423. doi:10.1007/s11266-015-9645-4

Zhao, R., Wu, Z., and Tao, C. (2016). Understanding Service Contracting and its Impact on Ngo Development in China. Voluntas 27 (5), 2229-2251. doi:10.1007/s11266-016-9714-3

Conflict of Interest: The author declares that the research was conducted in the absence of any commercial or financial relationships that could be construed as a potential conflict of interest.

Publisher's Note: All claims expressed in this article are solely those of the authors and do not necessarily represent those of their affiliated organizations, or those of the publisher, the editors and the reviewers. Any product that may be evaluated in this article, or claim that may be made by its manufacturer, is not guaranteed or endorsed by the publisher.

Copyright $\odot 2021$ Nasibov. This is an open-access article distributed under the terms of the Creative Commons Attribution License (CC BY). The use, distribution or reproduction in other forums is permitted, provided the original author(s) and the copyright owner(s) are credited and that the original publication in this journal is cited, in accordance with accepted academic practice. No use, distribution or reproduction is permitted which does not comply with these terms. 